\title{
Cold agglutinin-induced hemolytic anemia during room temperature fluid resuscitation: a case report
}

\author{
Yosuke Kawai* (, Miyoshi Deguchi, Naoko Mizouchi, Satoru Yoshida, Ken Kumagai and Yasuo Hirose
}

\begin{abstract}
Background: Cold agglutinin disease can cause the agglutination of red blood cells and hemolytic anemia due to cold temperature. Herein, we report a case of progressive hemolytic anemia due to cold agglutinin disease during fluid resuscitation and in the absence of exposure to cold.
\end{abstract}

Case presentation: A 71-year-old Japanese man was admitted to the emergency department with signs of hypotension and disturbed consciousness. He was diagnosed with diabetic ketoacidosis, and treatment with fluid resuscitation and insulin infusion was initiated. Laboratory test results obtained the following day indicated hemolytic anemia. On day 5 after admission, red blood cell agglutination was detected, and the patient was diagnosed with cold agglutinin disease.

Conclusions: Cold agglutinin disease should be considered in the differential diagnosis of progressive hemolytic anemia during fluid resuscitation, even if the solution is at room temperature.

Keywords: Cold agglutinin disease, Hemolytic anemia, Fluid resuscitation, Diabetic ketoacidosis, Intensive care

\section{Background}

Anemia in patients admitted to intensive care is a common and significant problem, with $90 \%$ of patients developing anemia by the third day after admission, and $97 \%$ by the eighth day [1]. The most common causes of anemia in intensive care unit (ICU) patients are chronic diseases (32.4\%) and blood loss (11.8\%), with hemolysis being the cause in only $2.9 \%$ of cases [2].

Cold agglutinin disease (CAD) can cause red blood cell (RBC) agglutination and extravascular hemolysis in patients exposed to cold temperatures, resulting in anemia. CAD is caused by high levels of circulating cold agglutinins (CAs). To avoid exposure to cold temperatures, maintenance of room temperature, protection of the extremities and acral areas of the face with warm

*Correspondence: yokawai-nii@umin.ac.jp Niigata City General Hospital Emergency \& Critical Care Medicine, 463-7 Shumoku, Chuo-ku, Niigata 950-1197, Japan clothing, and avoidance of cold food or liquid consumption are recommended. Cold intravenous solutions and transfusions should be avoided in hospitalized patients.

In this study, we present a case of a patient with diabetic ketoacidosis (DKA) and progressive anemia due to $\mathrm{CAD}$ during fluid resuscitation, despite the intravenous infusion being administered using a solution at room temperature.

\section{Case presentation}

A 71-year-old Japanese man was admitted to our hospital with signs of hypotension and disturbed consciousness. The patient had a history of type 2 diabetes, but due to treatment default he was not receiving any regular medication. There was no other specific medical, social, family, or surgical history. On examination, the patient appeared pale and ill, and he had livedo reticularis. The patient's blood pressure was $85 / 47 \mathrm{mmHg}$, pulse rate was $125 \mathrm{bpm}$, respiratory rate was 20 breaths/min with $\mathrm{O}_{2}$ original author(s) and the source, provide a link to the Creative Commons licence, and indicate if changes were made. The images or other third party material in this article are included in the article's Creative Commons licence, unless indicated otherwise in a credit line to the material. If material is not included in the article's Creative Commons licence and your intended use is not permitted by statutory regulation or exceeds the permitted use, you will need to obtain permission directly from the copyright holder. To view a copy of this licence, visit http://creativecommons.org/licenses/by/4.0/. The Creative Commons Public Domain Dedication waiver (http://creativeco mmons.org/publicdomain/zero/1.0/) applies to the data made available in this article, unless otherwise stated in a credit line to the data. 
saturation of $99 \%$ in room air, and rectal temperature was $33{ }^{\circ} \mathrm{C}$. The neck was supple. Results of the cardiovascular examination were normal, lungs were clear to auscultation, and the results of the abdominal examination were unremarkable. On neurological examination, his pupils were dilated to approximately $5 \mathrm{~mm}$ and were nonreactive to light; the Glasgow Coma Scale score was 6 (E4V1M1). Results from the initial laboratory tests revealed signs of macrocytic anemia (hemoglobin level $9.1 \mathrm{~g} / \mathrm{L}$, mean cell volume $112 \mathrm{fL}$ ), increased number of white blood cells $(25,800$ cells $/ \mu \mathrm{L})$, and elevated $\mathrm{C}$-reactive protein level $(40.4 \mathrm{mg} / \mathrm{L})$. The patient had hyperglycemia $(710 \mathrm{mg} / \mathrm{dL})$. The arterial blood gas test showed metabolic acidosis ( $\mathrm{pH}$ 6.723 , base excess $-32.1 \mathrm{mmol} / \mathrm{L}$ ) with an anion gap of 30.8. The urine test showed the presence of acetone bodies. Computed tomography without contrast of the whole body (head, chest-pelvis) showed bilateral pulmonary consolidation and mild pancreatic enlargement.

Based on hyperglycemia, presence of urinary acetone bodies, and metabolic acidosis with increased anion gap, the patient was diagnosed with DKA (Table 1). Initial treatment with fluid resuscitation $(2000 \mathrm{~mL}$ per $1.5 \mathrm{~h}$, lactated Ringer's solution), insulin intravenous bolus of $5 \mathrm{U}$ followed by intravenous continuous infusion $(3 \mathrm{U} / \mathrm{h})$, and active external rewarming with warm blankets was initiated in the emergency department. After the initial treatment, the patient was admitted to the ICU. Despite fluid resuscitation $(400 \mathrm{~mL} / \mathrm{h})$, hypotension persisted, and

Table 1 Laboratory data on admission

\begin{tabular}{|c|c|c|}
\hline Laboratory parameters & Patient's values & Reference range \\
\hline White blood cell (cells/ $\mu \mathrm{L})$ & 25,800 & $3300-8600$ \\
\hline Hemoglobin (g/dL) & 9.1 & $13.7-16.8$ \\
\hline$M C V(f L)$ & 112 & $83.6-98.2$ \\
\hline Platelets (cells/ $\mu \mathrm{L}$ ) & 291,000 & $158,000-340,000$ \\
\hline Sodium (mmol/L) & 135 & $138-145$ \\
\hline Potassium (mmol/L) & 5.1 & $3.6-4.8$ \\
\hline Chloride (mmol/L) & 102 & $101-108$ \\
\hline Urea nitrogen (mg/dL) & 60.2 & $8-20$ \\
\hline Creatinine $(\mathrm{mg} / \mathrm{dL})$ & 1.48 & $0.65-1.07$ \\
\hline C-reactive protein (mg/dL) & 4.42 & $<0.14$ \\
\hline AST (IU/L) & 55 & $13-30$ \\
\hline $\operatorname{ALT}(I U / L)$ & 30 & $10-42$ \\
\hline LDH (IU/L) & 526 & $124-222$ \\
\hline Total bilirubin (mg/dL) & 1.2 & $0.4-1.5$ \\
\hline Glucose (mg/dL) & 710 & 73-109 \\
\hline ABG: $\mathrm{pH}$ & 6.723 & $7.35-7.45$ \\
\hline ABG: bicarbonate $(\mathrm{mmol} / \mathrm{L})$ & 2.2 & $21-27$ \\
\hline Urine acetone body & $3+$ & \\
\hline
\end{tabular}

MCV Mean corpuscular volume, AST aspartate aminotransferase, ALT alanine aminotransferase, $L D H$ lactate dehydrogenase, $A B G$ arterial blood gas treatment with norepinephrine and vasopressin was initiated. Twelve hours after admission to the ICU, his glucose level had decreased to $385 \mathrm{mg} / \mathrm{dL}$, and $7600 \mathrm{~mL}$ of crystalloid fluid was administered. Complete blood count showed the progression of anemia. Biochemical analysis revealed elevated bilirubin levels, and he received a nonwarmed blood transfusion. On day 3 , his hemodynamic parameters improved. Thus, therapy with norepinephrine and vasopressin was discontinued, and the infusion rate was reduced (Table 2).

On day 5 of the patient's ICU stay, RBC agglutination was observed (Fig. 1). Based on RBC agglutination and elevated bilirubin levels, CAD was suspected. The result of the direct Coombs test was positive, and the CA titer test revealed an elevated autoantibody titer (1:8192 at $\left.4{ }^{\circ} \mathrm{C}\right)$. The patient was therefore diagnosed with CAD. No bacterial or viral infections causing CAD or DKA were detected (Table 3). He was discharged from the ICU on day 6. As a preventive measure, the patient was recommended to avoid cold exposure. During the hospital stay,

Table 2 Laboratory findings during patient's stay in the intensive care unit

\begin{tabular}{llllll}
\hline Laboratory parameters & \multicolumn{5}{l}{ Days after admission to intensive care unit } \\
\cline { 2 - 6 } & 1 & 2 & 3 & 4 & 5 \\
\hline Hemoglobin $(\mathrm{g} / \mathrm{dL})$ & 9.1 & 6.1 & $8.5^{\mathrm{a}}$ & 9.3 & 10.4 \\
Total bilirubin $(\mathrm{mg} / \mathrm{dL})$ & 1.2 & 5.0 & 1.1 & 1.8 & 1.5 \\
$\begin{array}{l}\text { Direct bilirubin }(\mathrm{mg} / \\
\mathrm{dL} \text { ) }\end{array}$ & 3.4 & 0.5 & 0.5 & \\
Infusion rate $(\mathrm{mL} / \mathrm{h})$ & $1500 \rightarrow 400$ & $400 \rightarrow 160$ & $160 \rightarrow 20$ & 20 & 20
\end{tabular}

Laboratory findings revealed progression of anemia with an elevation in total bilirubin levels accompanying a high infusion rate

a The patient received a transfusion of $560 \mathrm{~mL}$ of red blood cells on day 2

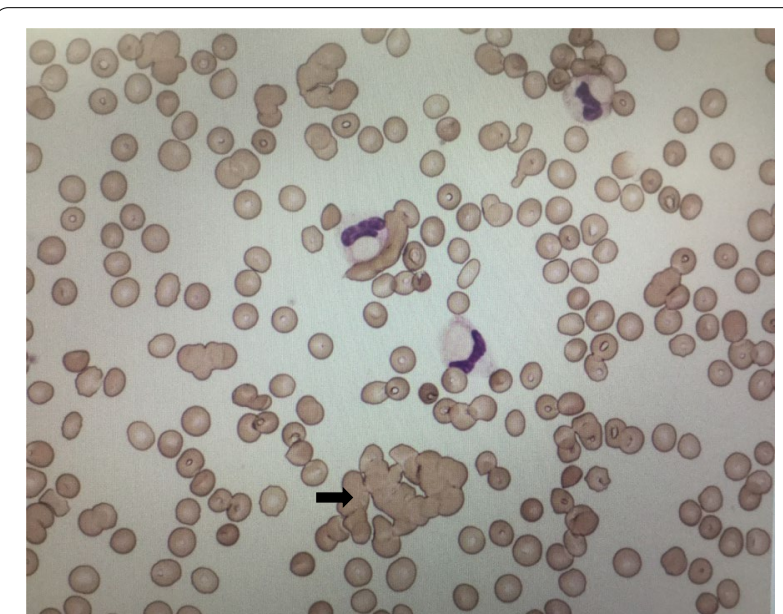

Fig. 1 Peripheral blood smear showing red blood cell agglutination (arrow) 
Table 3 Results of laboratory tests performed to diagnose cold agglutinin disease and determine background infections

\begin{tabular}{lll}
\hline Laboratory tests & $\begin{array}{l}\text { Patient's } \\
\text { results/values }\end{array}$ & Reference range \\
\hline $\begin{array}{l}\text { Direct Coombs test } \\
\text { Indirect Coombs test }\end{array}$ & Positive & \\
CA titer at $4{ }^{\circ} \mathrm{C}$ & Negative & \\
EBV VCA IgM & $1: 8192$ & $1:<256$ \\
EBV VCA lgG & $<10$ & $<10$ \\
EBNA & 160 & $<10$ \\
CMV antigenemia & 20 & $<10$ \\
CMV IgM & Negative \\
CMV IgG & Negative \\
Mycoplasma pneumoniae PA titer & Negative \\
Mycoplasma pneumoniae LAMP & $<40$ & \\
\hline
\end{tabular}

EBV VCA Epstein-Barr virus viral capsid antigen, EBNA EBV nuclear antigen, CMV Cytomegalovirus, Ig immunoglobulin, PA particle agglutination, LAMP loopmediated isothermal amplification

there was no recurrence of anemia. On day 32 following presentation, he was discharged from the hospital.

\section{Discussion}

A case of cold agglutinin disease is extremely uncommon in the emergency department. As our patient was not exposed to cold temperatures in the ICU, there was no suspicion of CAD at presentation. We therefore decided to investigate the mechanism of CAD hemolytic anemia during room temperature fluid resuscitation.

Previous studies have demonstrated that CAs bind to antigens on the surface of RBCs in the acral areas where the blood temperature is lower than the body temperature and that they recruit components of the complement pathways. Upon warming of the central circulation to body temperature, CAs detach from the RBCs, but $\mathrm{C} 3 \mathrm{~b}$ remains bound. Some of the $\mathrm{C} 3 \mathrm{~b}$-coated $\mathrm{RBCs}$ are trapped by macrophages mainly in the liver, resulting in extravascular hemolysis [3].

According to the pathophysiology described above, we considered two possible mechanisms of hemolytic anemia in this case. The first is that the rapid room temperature infusion decreased peripheral intravascular temperature, resulting in the activation of CAs. Although CAs usually agglutinate $\mathrm{RBCs}$ at $4{ }^{\circ} \mathrm{C}$, most clinically important CAs act at temperatures exceeding $28-30{ }^{\circ} \mathrm{C}$ [4]. A previous study showed that during a $30-\mathrm{min}$ infusion of $30 \mathrm{~mL} / \mathrm{kg}$ room temperature saline solution into healthy subjects, the core temperature decreased by $0.5^{\circ} \mathrm{C}[5]$. In light of this study, it is reasonable to suggest that rapid intravenous room temperature infusion also reduces peripheral intravascular temperature.
The second possible mechanism is that rewarming and subsequent improvement in hemodynamics by fluid resuscitation affect the delayed identification of hemolytic anemia. On admission, the patient had livedo reticularis, which is a manifestation of blood flow disturbance and vessel dilation. In CAD patients, agglutinated RBCs in the cooler peripheral areas cause a hyperviscosity of blood flow and blood stasis in the capillary venules, which in turn leads to livedo reticularis [6]. There is a possibility that our patient was exposed to cold temperatures before hospitalization. As active external rewarming was performed in the hospital, CAs then detached from RBCs, and capillary stasis was eliminated; at the same time, fluid resuscitation increased blood return to the central circulation, resulting in hemolysis of $\mathrm{C} 3 \mathrm{~b}$ coated RBCs in the liver.

There are some reports of incidental diagnosis of CAD in medical practice where the clinical symptoms presented intraoperatively during hypothermic cardiopulmonary bypass $[7,8]$. Barbara et al. recommend that patients with a history or evidence of hemolysis and agglutinations should undergo CA and thermal amplitude tests in conjunction with a hematologic consultation before cardiac surgery [9].

In addition, CAD should be a differential diagnosis of progressive hemolytic anemia during rapid intravenous infusion, even if the solution used is at room temperature. In emergency care, fluid resuscitation is often administered. In patients with hemolytic anemia, peripheral blood smear, Coombs test, and CA test should be performed, and infusion or transfusion should be changed to a warmed one.

\section{Conclusions}

In this report, we present a case of hemolytic anemia during fluid resuscitation of a patient with DKA. CAD should be considered as a differential diagnosis in patients developing hemolytic anemia during fluid resuscitation, even if the solution used for resuscitation is at room temperature.

\section{Abbreviations \\ CAD: Cold agglutinin disease; CA: Cold agglutinin; DKA: Diabetic ketoacidosis; ICU: Intensive care unit; RBCs: Red blood cells.}

\section{Acknowledgements}

Not applicable.

Authors' contributions

All authors participated in patient care. YK and YH prepared the manuscript. All authors read and approved the final manuscript.

\section{Funding}

No funding was obtained from any agencies. 
Availability of data and materials

Not applicable.

\section{Declarations}

\section{Ethics approval and consent to participate}

Not applicable.

\section{Consent for publication}

Written informed consent was obtained from the patient for publication of this case report and any accompanying images. Copies of the written consent are available for review by the Editor-in-Chief of this journal.

\section{Competing interests}

The authors declare that they have no competing interests.

Received: 29 February 2020 Accepted: 12 March 2021

Published online: 16 April 2021

\section{References}

1. McEvoy MT, Shander A. Anemia, bleeding, and blood transfusion in the intensive care unit: Causes, risks, costs, and new strategies. Am J Crit Care. 2013;22:eS1-13.
2. Tosiri P, Kanitsap N, Kanitsap A. Approximate iatrogenic blood loss in medical intensive care patients and the causes of anemia. J Med Assoc Thail. 2010;93(Suppl 7):S271-6.

3. Swiecicki PL, Hegerova LT, Gertz MA. Cold agglutinin disease. Blood 2013:122:1114-21.

4. Baines AC, Brodsky RA. Complementopathies. Blood Rev. 2017;31:213-23.

5. Moore TM, Callaway CW, Hostler D. Core temperature cooling in healthy volunteers after rapid intravenous infusion of cold and room temperature saline solution. Ann Emerg Med. 2008;51:153-9.

6. Copeman PW. Livedo reticularis. Signs in the skin of disturbance of blood viscosity and of blood flow. Br J Dermatol. 1975;93:519-29.

7. Patel PA, Ghadimi K, Coetzee E, Myburgh A, Swanevelder J, Gutsche JT, et al. Incidental cold agglutinins in cardiac surgery: intraoperative surprises and team-based problem-solving strategies during cardiopulmonary bypass. J Cardiothorac Vasc Anesth. 2017;31:1109-18.

8. Kanemitsu S, Onoda K, Yamamoto K, Shimpo H. Simple preoperative management for cold agglutinins before cardiac surgery. J Thorac Cardiovasc Surg. 2010;140:e73-4.

9. Barbara DW, Mauermann WJ, Neal JR, Abel MD, Schaff HV, Winters JL. Cold agglutinins in patients undergoing cardiac surgery requiring cardiopulmonary bypass. J Thorac Cardiovasc Surg. 2013;146:668-80.

\section{Publisher's Note}

Springer Nature remains neutral with regard to jurisdictional claims in published maps and institutional affiliations.
Ready to submit your research? Choose BMC and benefit from:

- fast, convenient online submission

- thorough peer review by experienced researchers in your field

- rapid publication on acceptance

- support for research data, including large and complex data types

- gold Open Access which fosters wider collaboration and increased citations

- maximum visibility for your research: over $100 \mathrm{M}$ website views per year

At BMC, research is always in progress.

Learn more biomedcentral.com/submissions 